Gi respons på artikler gjennom artiklenes kommentarfelt på tidsskriftet.no.

Innleggene publiseres fortløpende på Tidsskriftets nettside og et utvalg

av innleggene publiseres også i papirutgaven i spalten «Brev til redaktøren».

Redaksjonen forbeholder seg retten til å foreta redaksjonelle endringer.

Forfattere av vitenskapelige artikler har tilsvarsrett, jf. Vancouver-gruppens regler.

\section{Re: Kjernejournalen som arbeidsverktøy?}

Jon Haffner har i Tidsskriftet skrevet om sine egne erfaringer med elektronisk pasientjournal, både som erfaren lege og som pasient (1). Han setter søkelyset på et viktig område for helsetjenesten og Legeforeningen: Utviklingen innenfor e-helse generelt og elektronisk pasientjournal spesielt.

Legeforeningen ønsker en aktiv debatt rundt e-helse. Leger ønsker IT-løsninger som bidrar til kvalitet og effektivitet i pasientbehandlingen, og morgendagens helsetjeneste vil i økende grad være avhengig av IKT-støtte og elektronisk samhandling - også med pasientene. Klinikernes behov og vurderinger er i dag ikke godt nok ivaretatt når nye IKT-verktøy utvikles og tas i bruk. Det er pasientene som rammes når dårlig arbeidsflyt, manglende beslutningsstøtte og sviktende elektronisk samhandling for ofte preger hverdagen i helsetjenesten.

På nasjonalt nivå skjer satsingen nå basert på føringene i Stortingsmelding nr. 9 (2012-2013) Én innbygger - én journal. I denne stortingsmeldingen er rask tilgang til nødvendig informasjon for både helsearbeider og pasient, uavhengig av hvor pasienten sist ble behandlet, et sentralt målbilde som Legeforeningen støtter. Økt struktur i elektroniske pasientjournaler er også løftet frem i stortingsmeldingen som et satsingsområde som skal gi pasientene et bedre helsetilbud. Det er tydelig at det for tiden hersker en sterk tro på at mer struktur i pasientjournal vil fremme bedre digital samhandling og gi enklere gjenbruk av data for kvalitets-, forsknings-, styrings- og kontrollformål, mens det kliniske primærformålets behov i mindre grad belyses i de førende dokumenter, annet enn på et helt overordnet nivå.

Legeforeningen har gitt tydelige innspill til Helsedirektoratet på mål, krav og konseptalternativer for «En innbygger - én journal». Legeforeningens IT-utvalg har i prosessen utarbeidet en omfattende faglig gjennomgang av nytte og ulemper ved økt bruk av struktur og arketyper i elektronisk pasientjournal (2). Basert på IT-utvalgets grundige faglige vurderinger har Legeforeningen utformet et policynotat (3) med tittelen «Slik må fremtidens pasientjournal skapes».

Nasjonal kjernejournal er en viktig del av den nasjonale satsingen på bedre tilgang til nødvendig - og for kjernejournalens vedkommende - kritisk helseinformasjon «at the point of care». Legeforeningen støtter utviklingen av nasjonal kjernejournal, men ser at utvikling og pilotering avdekker betydelige utfordringer knyttet til både etablering av medisinsk faglig informasjon om den enkelte pasient, og helsepersonellets faktiske bruk og nytte av informasjonen. Disse utfordringene er kjent også fra andre land som har implementert lignende informasjonssystemer. Legeforeningen har nylig avgitt en høringsuttalelse om dette til Helsedirektoratet, hvor konkrete risiko- og forbedringsområder er påpekt (4).

Legeforeningen er avhengig av at våre medlemmer er aktive når fremtidens journalsystemer skal utvikles. Derfor er det kjærkomment at denne debatten også går i Tidsskriftets spalter, slik Jon Haffner nå har bidratt til. Det arbeidet som hele Legeforeningens organisasjon nedlegger på dette området er formidabelt, og behovet er økende. Vi må stadig utvikle vår ekspertrolle innenfor e-helse, hvor en samlet spisskompetanse på både informatikk og medisinsk fagutøvelse gjør Legeforeningen til en helt nødvendig samarbeidspartner når myndighetene har tatt føringen for å utvikle fremtidens løsninger.

\section{Hege Gjessing}

Hege.Gjessing@legeforeningen.no

Hege Gjessing (f. 1972) er president i Den norske legeforening.

Ingen oppgitte interessekonflikter.
Litteratur

1. Haffner J. Kjernejournalen som arbeidsverktøy? Tidsskr Nor Legeforen 2015; 135: 112.

2. Om strukturering av medisinsk informasjon i elektroniske pasientjournaler. Legeforeningens IT-utvalg 2015. http://legeforeningen.no/Emner/Andre-emner/ Publikasjoner/policynotater/ (29.4.2015).

3. Slik må fremtidens pasientjournal skapes. Legeforeningens policynotat nr. 2/2015. http://legeforeningen.no/Emner/Andre-emner/Publikasjoner/policynotater/ Policynotater-2015/Slik-ma-fremtidens-pasientjournal-skapes-22015--/ (29.4.2015).

4. Høring. Rapport 2.0 for «Kritisk informasjon for kjernejournal». Legeforeningen 21.4.2015. http://legeforeningen.no/Legeforeningen-mener/Horingsuttalelser/ 2015/Horing-Rapport-20-for-Kritisk-informasjon-for-kjernejournal---/(29.4.2015).

\section{J. Haffner svarer:}

Jeg er imponert av det arbeidet Legeforeningen og en rekke andre aktører har gjort med Nasjonal kjernejournal og i den pågående prosess etter Stortingsmeldingen «Én innbygger - én journal».

Men kjernejournalen er ikke det arbeidsdokumentet vi leger trenger. Som Arnesen og Larsen skriver i sin artikkel om kjernejournal (1), er den en samling av opplysninger som kan gi helsepersonell viktige opplysninger om pasienten på steder der han/hun ikke har noen journal.

Målsetningene i «Én innbygger - én journal» er meget ambisiøse, og dekker nesten all dokumentasjon om pasienten. Det er vanskelig å vurdere en prosess man ikke har deltatt i, men det er mitt inntrykk at arbeidet til nå stort sett har bestått $\mathrm{i}$ å vurdere hvordan man kan få flest mulige opplysninger om pasienten inn $\mathrm{i}$ journalen, både medisinske og administrative, og hvordan moderne informasjonsteknologi best kan brukes. Ressursbruken til registreringene, og hva som skjer med journalen som arbeidsverktøy later til å ha fått liten oppmerksomhet.

Legeforeningen har ikke vært i førersetet, og var faktisk ikke engang representert i Styringsgruppen den første tiden. Men den viktigste oppgaven journalen har, er å sikre best mulig pasientbehandling, og der er det vi leger som har hovedrollen. Så vidt jeg vet arbeider Legeforeningen nå med å sørge for at det kliniske primærformålet med journalen får prioritet og blir førende, ikke journaluttrekk til kontroll, styring, rapportering, DRG finansiering, kvalitetsarbeid og forskning. Det er utmerket!

Arbeidet med journalen har i hovedsak vært ivaretatt av foreningens IT-utvalg, som har størst kompetanse i IT, men trolig også størst entusiasme for bruken av den teknologien. Jeg tror fortsatt det ville være nyttig å ha et utvalg eller underutvalg som kan vurdere hva hvert enkelt forslag vil bety for journalen som arbeidsverktøy. Medlemmene av det utvalget bør ha dobbelterfaring i bruk av journalen både som leger og pasienter, de behøver ikke ha spesialkompetanse i IT, siden de skal representere brukerne. Vi foreslo på Legeforeningens landsstyremøte i fjor at pensjonerte leger skulle trekkes inn i arbeidet fordi de stort sett har mer tid til rådighet enn leger i fullt arbeid.

Jeg mener fortsatt at det er behov for redigering og oppsummering, men inntil det kan gjennomføres ønsker jeg meg et førstebilde på skjermen når en pasient hentes opp, hvor det i tillegg til navn og fødselsdato også står aktuell diagnose og behandling (med tid for start), og prøver og undersøkelser siden forrige konsultasjon. Da kan man straks fokusere på pasienten.

\section{Jon Haffner}

Jon.Haffner@gmail.com

Jon Haffner (f. 1940) er pensjonert kirurg.

Ingen oppgitte interessekonflikter.

Litteratur

1. Arnesen EN, Larsen BA. Kritisk informasjon i kjernejournal. Tidsskr Nor Legeforen 2014; 134: 1927-8 